\title{
19 \\ Overturning Aqua Nullius: Pathways to National Law Reform
}

\author{
Virginia Marshall ${ }^{1}$
}

\section{Background and Introduction}

The purpose of this chapter is to identify and propose new pathways to reform legal issues affecting Indigenous people in the exercise of their traditional and revitalised rights and interests in water within national and state water regimes. I argue that the exercise of traditional and revitalised laws as expressed in Art 11 of the UN Declaration on the Rights of Indigenous Peoples (UNDRIP) should be incorporated into Australia's water laws and policies, in addition to other articles of the Declaration, for example Art 20, for Indigenous peoples to develop economic opportunities in water. These and other relevant international instruments incorporated into Australian law would give expression to the exercise and enjoyment of traditional and revitalised rights to water, economic and cultural property rights and interests, to create substantive pathways for Indigenous First Peoples of Australia.

The colonisation of Australia into existing states and territories was staggered over temporal phases, and the nation state progressively excluded, controlled and marginalised Indigenous communities' cultural

1 Principal Solicitor, Triple BL Legal. 
and economic water rights and interests. Pathways to water reform must acknowledge that there have been few opportunities for Indigenous communities in Australia to advance and strengthen their own economy:

The boundaries to the ownership and control of water and other resources inherent to Indigenous peoples have been defined by the Crown. The Commonwealth water legislation has clearly defined the parameters of the rights and interests of Indigenous peoples' water resources. The exercise of water rights in Australia by Aboriginal communities historically turns on 'government political will' to include Aboriginal peoples in policy and legislative development. ${ }^{2}$

Private property rights lie at the heart of Western market-based economies such as Australia, where alienable freehold land and tradeable water rights generate wealth, and prevail over native title rights and interests. Although the concept of private property rights in water is not new, as 'the Romans legislated individual property rights to regulate water use', ${ }^{3}$ it is new for Indigenous peoples of Australia.

There is a need to create new concepts of water tenure and property models which do not leave Indigenous communities vulnerable to forfeit on default in failing to meet their legal obligations. Any proposed reform to the Australian Government's water policy and laws requires the full review of the National Water Initiative which should be subject to the scrutiny of human rights principles such as UNDRIP. The Organisation for Economic Co-operation and Development (OECD) baseline projection is that 3.9 billion people will be subject to severe water stress by 2050. ${ }^{4}$ The OECD Taskforce on Water Security and Sustainable Growth states that:

the goal of improving material wealth of societies must be negotiated within the boundaries imposed by the availability and sustainability of the water resource, and balanced with the cultural and spiritual values of water. $^{5}$

2 Virginia Marshall, $A$ Web of Aboriginal Water Rights: Examining the Competing Aboriginal Claim for Water Property Rights and Interests in Australia (PhD Thesis, Macquarie University, 2014) 225.

3 Joshua Getzler, A History of Water Rights at Common Law (Oxford University Press, 2006) 11.

4 C W Saddoff et al, 'Securing Water, Sustaining Growth: Report of the GWP/OECD Task Force on Water Security and Sustainable Growth' (2015) 30.

5 Ibid. 39. 
The creation of Australian property rights in water was enacted by the statutory separation of water from land. National Water Reform was 'intended to create effective water management and certainty for business and industry' including 'investment in water trading. ${ }^{6}$ Indigenous peoples were afforded the incorporation of discretionary Indigenous Clauses in the 'blueprint for national water reform' under the National Water Initiative, which relegated the status of Indigenous peoples to one of many minority interests in water. The recent progress for Aboriginal peoples' water interests in the Murray-Darling Basin was a result of the parliament's amendment of s 202(5)(c) of the Water Act 2007 (Cth) to include 'at least 2 Indigenous persons with expertise in Indigenous matters relevant to the Basin's water resources'. ${ }^{7}$ Such amendments are inadequate.

The background to the exploration of an Indigenous water discourse should acknowledge that water resources are framed by a Western postcolonial legacy which 'built' Australia's wealth by fortifying control through state and federal constitutions to secure rights to water and land tenure. Observations by settlers and the establishment were cognisant of the presence of Indigenous peoples, their laws, customs and practices, often tolerating coexisting water use in the expectation that it would not impede Western modes of economic development. Australian governments have 'historically given water entitlements to farmers for free and encouraged them to utilize available water'. ${ }^{8}$

On the one hand Australian water management by the colonial founders estranged Indigenous communities from continuing to participate in their historic Indigenous economies. On the other hand those same colonial constructs were apparent during the government's national water reform process with the lack of inclusion of Indigenous rights and interests and offering limited scope in this process to address repugnant historical water policies such as the treatment of Indigenous water rights as aqua nullius and 'belonging to no one'.?

6 Marshall, above n 2, 323. Citing the National Water Commission, 'Australian Water Reform 2009: Second Biennial Assessment of Progress in Implementation of the National Water Initiative' ('Report', Australian Government, 2010) 104. See also Dr Virginia Marshall, Submission No 21 to Australian Government, Productivity Commission, National Water Reform, 18 April 2017.

7 See Virginia Marshall, 'The Progress of Aboriginal Water Rights in the Murray-Darling Basin in NSW: An Essential Element of Culture' (2015) Australian Environment Review 158.

8 Seamus Parker and Robert Speed, 'Agricultural Water Pricing: Australia' (Background Report, to the OECD Study 'Sustainable Management of Water Resources', 2010) 7.

9 Dr Virginia Marshall, Overturning Aqua Nullius: Securing Aboriginal Water Rights (Aboriginal Studies Press, 2017). 


\section{Indigenous Water Rights as 'First Rights'}

National water reforms have failed to recognise Indigenous peoples 'first rights' in Australia's water use timeline. The concept of first rights is to clearly express that Indigenous people of Australia were, and continue to be, the 'first right' water users; a concept drawn from water concepts recognised for native peoples in the US as either 'prior appropriation' for beneficial water use or 'first in time' use for riparian water right use. ${ }^{10}$ Indigenous peoples of Australia seek to exercise their legal and cultural rights for economic development as well as a sui generis use of water resources; for example, through native title, water trading, cultural heritage protection and cultural activities; in conjunction with the exercise of other statutory and common law land rights regimes established for Indigenous peoples.

The Crown's treatment of any purported continuing existence of Aboriginal people's rights to land and waters, prior to the High Court decision in Mabo v Queensland (No 2), ${ }_{11}^{11}$ concurred that such rights did not survive annexation, based upon the doctrine of terra nullius. Similarly the concept of aqua nullius, that is, 'water that belongs to no other', raises important questions that align equally with discourse on Indigenous land rights and are generally ignored in the broader discussion on property rights in water. Pre-colonial Indigenous tenure is expressed in Mabo (No 2) as 'special collective rights vested in an Aboriginal group by virtue of its long residence and communal use of land or its resources.. ${ }^{12}$

The Mabo (No 2) decision highlights the importance of incorporating international law into Australia's water law. The majority in the High Court Mabo (No 2) decision concluded that s 9 of the Racial Discrimination Act 1975 (Cth) $(R D A)$ referred to the enjoyment or exercise of fundamental freedoms' from Art 5 of the International Convention on the Elimination of All Forms of Racial Discrimination (CERD) but found it did not

10 See Michael C Blumm, 'Federal Reserved Water Rights as a Rule of Law' (2016) 52 Idaho Law Review 369. See also Robert T Anderson, 'Water Rights, Water Quality, and Regulatory Jurisdiction in Indian Country' (2015) 34(2) Stanford Environmental Law Journal 195.

11 (1992) 175 CLR 1.

12 Ibid. 33, Mabo $v$ Queensland (No 2) HC judgement. 
contravene 'the enjoyment of the applicant's traditional title'. ${ }^{13}$ The court then turned its mind to $R D A$ s 10 which referred to Art 5 that 'the right to be immune from arbitrary deprivation of property is a human right'. ${ }^{14}$

The incorporation of CERD and UNDRIP into Australia's water policies and laws would enshrine water as a human right and, as in Mabo (No 2), 'draw upon international law and concepts of equality and social justice' to consider whether Australia has met its legal obligations. First Peoples' rights in water should be exercised as human rights. The Australian Law Reform Commission (ALRC) identified that the UNDRIP principles represent a 'principled way of moving forward' in the recognition and protection of Indigenous peoples' rights and interests. ${ }^{15}$

The ALRC proposes the concept of 'moving forward' as a 'platform for engagement on Indigenous issues'. ${ }^{16}$ However, in relation to Indigenous water rights and interests, there is a conceptual national framework for Australia's water resources which should have prioritised Indigenous peoples as First Peoples in the hierarchy of water users, and not as a stakeholder. It is a matter of urgency that Indigenous water rights and interests require governments and other sector interests in water to recognise Indigenous communities as 'first use' rights and not a minority interest stakeholder in the consumptive and non-consumptive pools. The centrality of First Nation water use, ownership and management of water operates under the Indigenous rule of laws, ${ }^{17}$ and the framework to understanding the use, management and ownership of water, collectively or otherwise.

13 Mabo (No 2) $v$ Queensland 175 CLR 1.

14 Ibid.

15 Australian Law Reform Commission, Connection to Country: Review of the Native Title Act 1993

(Cth), Final Report No 126 (2015) 82-85.

16 Ibid. 85.

17 The Indigenous ontological understanding of the Indigenous rule of laws is not singular. See Dr Virginia Marshall, 'Deconstructing Aqua Nullius: Reclaiming Aboriginal Water Rights and Communal Identity in Australia' (2016) 8/26 Indigenous Law Bulletin. 


\section{The Indigenous Rule of Law and Rights to Water}

The communal nature of Indigenous water rights, or land rights, as a property right is not a contested concept among Indigenous communities in Australia; for example, the permission or denial of entering 'country' underpinned by Indigenous laws has clear consequences far more severe than Australia's breach of trespass law. Unlike Western property rights, Indigenous property rights are connected to 'country and place' by birth and death in familial connection, ${ }^{18}$ in a gendered environment ${ }^{19}$ and defined by ancient boundaries. ${ }^{20}$ The territorial association and ceremonial relationships' to country is tenure, and Indigenous laws that provide for the rules of succession enable the Indigenous rule of law to survive.

Michael Kirby noted in his paper 'The Rule of Law beyond the Law of Rules' that 'compliance with the letter of the law is an idea that lies at the very heart of the purpose of law in every society'. ${ }^{21}$ Further, Kirby argues that we should be 'concerned with the content of the rule of law and procedures' to mitigate against 'prejudice and unequal treatment'. ${ }^{22}$ Indigenous laws 'are at the heart' of Indigenous culture, its communities and social order.

In Australian society Western interpretations of Indigenous laws were poorly conceptualised, for example, into categories of culture, spirituality, mythology, knowledge and heritage, wherein the treatment of Indigenous language, painting, ceremony, sites and familial relationships are considered somehow divisible parts of Indigenous laws. The Indigenous rule of law over water rights 'lies within an Aboriginal concept where Aboriginal laws determine that water is inseparable from the land'. ${ }^{23}$

18 Marshall, above n 2, 163-64.

19 Ibid. 165.

20 Ibid. 187.

21 Michael Kirby, 'The Rule of Law beyond the Law of Rules' (2010) 33(3) Australian Bar Review 197.

22 Ibid. 210.

23 Dr Virginia Marshall, 'The Progress of Aboriginal Water Rights and Interests in the MurrayDarling Basin in NSW: An Essential Element of Culture' (2015) Australian Environment Review 158. 
Indigenous water knowledge and the laws which connect to the creation story establish the permissible use of water, the types of activities and purposes for water use and the obligations to maintain the health and quality of water, among other things. ${ }^{24}$ Article 34 of the UNDRIP expresses the 'rights to promote, develop and maintain their institutional structures, customs, procedures, among other things'. The recognition of the Indigenous rule of law into Australian water laws and policies elevates the status of Indigenous peoples as 'First Peoples' and not stakeholders.

\section{Northern Australian Development and the Tenure Reform}

The Australian Government's proposal to develop northern Australia 'as a trade gateway' ${ }^{25}$ set out in 'Our North, Our Future: White Paper on Developing Northern Australia' (2015) raises significant issues in regards to water, and land use. The development proposal is based upon 'five pillars' to realise growth: food and agribusiness, resources and energy, tourism and hospitality, international education, healthcare, medical research and aged care. ${ }^{26}$ All of the government's 'five pillars' require access to water and high abstraction levels, with the highest water abstractions sought by food, agribusiness, resources and energy. The government points out that 'without secure, tradeable titles to land and water ${ }^{27}$ it flounders, as the majority of land is held under 'pastoral leases and exclusive native title'. ${ }^{28}$ The government requires unlimited 'groundwater and surface water' to 'attract investors to build water infrastructure' and 'access' ${ }^{29}$ Such plans include amending the definition of native title rights to include 'commercial use where exclusive native title rights are held'. ${ }^{30}$

To date, native title rights have been deemed solely for traditional noneconomic purposes; however, the recent High Court decision in Akiba $v$ Commonwealth [2013] HCA 33 recognised 'commercial purposes'. The Australian Government recognises that any development of northern

24 Ibid. 12, citing Walmajarri Senior Lawman Joe Brown describing laws for water.

25 Australian Government, 'Our North, Our Future: White Paper on Developing Northern Australia' (White Paper, Australian Government, 2015) 2.

26 Ibid. 3.

27 Ibid. 5.

28 Ibid. 5-6.

29 Ibid. 6.

30 Ibid. 11. 
Australia 'needs to be done in full partnership with Indigenous peoples' ${ }^{31}$ and 'access to water is a key constraint to develop the north', ${ }^{32}$ where northern lands and waters are largely exclusive rights held by Indigenous native title holders. The Australian Law Reform Commission inquiry into a review of the Native Title Act 1993 (Cth) highlighted that Australia has not met its international obligations for Indigenous peoples of Australia; the United Nations International Covenant on Economic, Social and Cultural Rights (ICESCR) Committee noted concerns on the 'high cost, complexity and strict rules regulating native title claims and the inadequate protection of Indigenous cultural and intellectual property'. However, the government's proposal to 'streamline the process' and 'remove red tape' to provide 'long term water security for farmers and investors ${ }^{\text {'33 }}$ is highly problematic because of the absence of independent evidence on the longterm impacts for Aboriginal water use and upon Aboriginal lands, waters and resources, as well as the cultural and heritage impact.

The consideration of the Australian Government reforms would create a substantive move away from the narrow sui generis interpretation of the Native Title Act 1993 (Cth) as expressed in s 223(1) which defines native title and the rights and interests comprised in s 223(2). The key aspects of the Australian Government's 'White Paper' directly affect the security of Indigenous water rights and it will have direct implications for Indigenous communities across Australia, including the impact of water reform.

\section{Expanding the Concept of Cultural Water Use}

In terms of Western policy concepts these 'customs and practices' are often couched in expressions of culture such as 'cultural flows ${ }^{34}$ and 'cultural licences' that extend to beneficial water use. The complex legal interpretation of native title rights to water under s 211 of the Native Title

31 Ibid. 4.

32 Ibid. 50.

33 Ibid. 11-12.

34 Cultural flows are by application for approval for water supply works, and/or water use under s 92 of the Water Management Act 2000 (NSW). 
Act 1993 (Cth) for usufructuary rights and the type of activities that are permitted in personal, domestic and non-economic use ${ }^{35}$ limit the full expression of Indigenous water rights and interests.

The Aboriginal concept of cultural water use is 'bound to Aboriginal peoples' relationship with the Aboriginal environment (lands and waters of Australia) based upon the founding Aboriginal principle of the inseparability of land from water'. ${ }^{36}$ The Commonwealth water legislation such as the Water Act 2007 (Cth) $)^{37}$ 'decouples Aboriginal ontological water concepts (Aboriginal norms) from its statutory provisions'. ${ }^{38}$ Aboriginal water values, law and cultural expressions are not separate from environmental water flows; in fact, Aboriginal cultural flows and Aboriginal cultural activities in water inform on maintaining the health of Australia's Aboriginal environment.

The statutory cultural flows for communal and cultural activities are restrictive and conditional; for example, for a specific purpose water access licence (WAL) up to 10 megalitres per year under s 61(1)(a) of the Water Management Act 2000 (NSW), subject to the Water Management (General) Regulation 2004, the licence can be made under the water sharing plan. However, if there are low or no flows identified in the water sharing plan, a WAL will not be granted. ${ }^{39}$ These types of licences provide limited opportunities for Indigenous peoples to exercise their laws, customs and practices.

A study undertaken by the UN Permanent Forum on Indigenous Issues in 2016, in relation to Indigenous peoples of the Pacific, sought that policy and legislative measures be implemented to protect and maintain the traditional knowledge of Indigenous peoples and their relationships

\section{Native Title Act 1993 (Cth) s 211.}

36 Dr Virginia Marshall, Overturning Aqua Nullius: Securing Aboriginal Water Rights (Aboriginal Studies Press, 2017) 145.

37 Ibid. Marshall raises the inconsistency in s 20(b) of the Water Act 2007 (Cth) which refers to the 'purpose of the Murray-Darling Basin Plan' to set 'environmental limits' to 'protect land and waters valued by Aboriginal peoples'. However, the water legislation does not elaborate on what compliance mechanisms could enforce the protection of Aboriginal cultural water values or the role of engagement for Aboriginal communities in the Murray-Darling Basin region and to inform governments on the 'environmental sustainability' through Aboriginal water knowledge.

38 Ibid.

39 NSW Office of Water, www.water.nsw.gov.au/water-management/water-sharing; www.water. nsw.gov.au/water-licensing/about-licences/new-access-licences. 
within their constitutions. ${ }^{40}$ The Australian Constitution does not include provisions to protect and maintain traditional knowledge regimes of Indigenous peoples and this should be considered in any review of issues relating to water, land and resources. It has been suggested that the current Australian debate on Indigenous Constitutional Recognition should include the Aboriginal recognition in water law. ${ }^{41}$

This national dialogue has failed to include substantive issues to address Indigenous water rights and interests such as perpetual water allocations outside the consumptive pool, a Reserved Indigenous Water Rights ${ }^{42}$ regime on a 'first rights user' basis, the exclusion of caps on native title water rights and an Aboriginal Water Holder model to facilitate intergenerational equity for Indigenous peoples. Defining the parameters of Indigenous water rights and interests as either cultural or economic concepts applies a rigidity which narrows future opportunities for Indigenous communities to adapt to the challenges of changing climatic conditions and global water scarcity.

\section{Conclusion}

The principles of human rights are instrumental in achieving the full participation of Indigenous water rights and interests in Australia, and the language of UNDRIP provides formative instruments to incorporate into Australia's domestic law and policy on water. Australia's water policy has advantaged sectional stakeholders and disadvantaged First Peoples, securing a tranche of water reform for themselves and merely discretionary provisions for Indigenous peoples. While Australia delays the legal recognition of equitable water reforms, the potential prospects for Indigenous ownership continue to diminish.

40 V Toki, Study on the Relationship between Indigenous Peoples and the Pacific Ocean, UN ESC, Permanent Forum on Indigenous Issues, Agenda Item 3, E/C.19/2016/3 (19 February 2016) 6.

41 Environmental Justice Australia, 'Aboriginal Water Rights: Legal analysis of Submissions to the Review of the Commonwealth Water Act' (Submission, Environmental Justice Australia, 20 November 2014) 7.

42 See the recommendations proposed by the author in Overturning Aqua Nullius: Securing Aboriginal Water Rights (Aboriginal Studies Press, 2017) 216-24. 
This text is taken from New Directions for Law in Australia: Essays in Contemporary Law Reform, edited by Ron Levy, Molly O’Brien, Simon Rice, Pauline Ridge and Margaret Thornton, published 2017 by ANU Press, The Australian National University, Canberra, Australia. dx.doi.org/10.22459/NDLA.09.2017.19 